\title{
Essay \\ Reflections on Reading the Scriptures as an Orthodox Christian
}

\author{
Mary Ford \\ St. Tikhon's Orthodox Theological Seminary in South Canaan, PA 18459, USA; mary.ford@stots.edu
}

Received: 13 April 2017; Accepted: 15 June 2017; Published: 5 July 2017

\begin{abstract}
The heart of the differences between an Orthodox understanding and use of Scripture, and what has prevailed in most non-Orthodox scholarly circles since the time of Spinoza, is not primarily anything to do with methodologies, or techniques as such, but fundamentally it is about the theological context within which the methods are used. Hence this paper begins by outlining the fundamentals of theology that undergird all traditional Orthodox exegesis. These fundamentals of Orthodox theology and life provide a radically different interpretive context for the use of any methods or tools of interpretation from that of the essentially agnostic approach promoted by Spinoza and those following him, who have exclusively used the historical critical method, whose foundational principle was to "interpret as if there is no God." Hence, from an Orthodox perspective, all the basic technical aspects of historical criticism - linguistic studies, looking at the historical context, etc.-when used within a traditional Christian interpretive context can be valuable tools leading to a deeper understanding. However, the ultimate purpose of properly interpreting Scripture-salvation, becoming holy-is achieved primarily through living the gospel.
\end{abstract}

Keywords: Orthodox Christian Tradition; Biblical interpretation; Fathers; historical criticism; the historical-critical method; salvation; gospel

"The Church does not give us Holy Scripture as a book to study and interpret on our own. Rather, it opens to us the door of that beauty to which we are called by the Bridegroom Himself."(Vasileios 2012, p. 105)

All understandings of, uses of, and methodologies for interpreting Scripture ultimately arise from the theology and world-view of those who develop and embrace them-and these include why interpreting Scripture is considered a valuable undertaking in the first place. Thus, for a proper understanding of the interpretation of Scripture in the Orthodox Church and her Tradition, it is important to give a little of the theological foundation. Of course, in a short article only a brief overview can be given.

In this article I will focus on eight foundational beliefs and a few additional key elements necessary for understanding how Scripture is used and interpreted within the Orthodox Church.

I. First, and most foundational, is the fact that God is real and has revealed Himself most fully in Jesus Christ as the good God Who loves mankind (a phrase repeated frequently in Orthodox worship services). Thus, because He is this good God, He does everything for our benefit in the sense of our ultimate benefit, our salvation-even to the point of the extreme humility of a voluntary death on the cross for our sakes. Therefore, Holy Scripture is considered to be a great gift of this good God, inspired by His Holy Spirit, in order primarily to help people in all times and places in their life's journey to come to know this good God through communion with Him, and to come to know various spiritual realities.

Thus, Scripture is seen as a kind of guide book on how to benefit spiritually from reality as it truly is (in contrast to how it is often perceived by the fallen mind), and on how to live in such a way as to be healed and transformed - to be able to purify one's heart so that one can acquire grace and live eternally in loving communion with God in Christ through the Holy Spirit. In other words, to fulfill the 
purpose for which we were created, to be saved. This is the approach we find in the New Testament itself-as for example, when St. Paul says about people and events recorded in the Old Testament, "Now all these things happened to them for examples, and they were written for our admonition..." (1 Cor. 10:11).

To use a different analogy, we could say that Scripture's intended role is understood to be not primarily to provide us with interesting historical information (though it can do that), but ultimately to provide us with "glasses" permitting us to see more and more clearly the way things truly are-so that we can move forward on the spiritual journey that is our life, so that we can move forward and eventually "take off."

As Archimandrite Vasileios, a highly respected Athonite spiritual father and theologian, says:

I listen to some theories or "theologies" which are like airports with no runway for takeoff. These are the things which restrict man and abuse the aeroplane. The aeroplane has to take off-it is not a push-cart you can use to sell tomatoes from in the market. It has a different destiny. And man too has a different destiny (Vasileios 1997, pp. 49-50).

Before the runway ends, it [the airplane] has found a different means of support, and so it doesn't have a crash. Before this life ends, man has to find a different means of support. And by the time death comes, he no longer treads this earth (Vasileios 1997, pp. 49-50).

Scripture, properly interpreted, helps people to find that "different means of support." We can see that for the Church Fathers and Saints, this personal transformation through grace is the primary purpose of reading/interpreting Scripture. We see this not only from their explicit statements, but also from the analogies they have frequently made through the ages about Scripture. In Scripture itself, we find it being compared to a light— "Thy word/law is a lamp unto my feet" (Ps. 119:105)—which illumines a way of life which, when we follow it, enables us to see Jesus Christ, the God-Man, Who most perfectly reveals the One True God-and to know that this God is the good God Who loves mankind.

The Scriptures are described by the Fathers as being like wells (holding the water of the Holy Spirit, Who transforms our lives); water; living water; succulent food; medicines; healing plaster for wounds; tree leaves that heal; yeast (that transforms the whole lump of dough); a weapon; armor; leaves that protect and shield; a beacon light, guiding us safely; and a counselor, keeping us on the right path, protecting us from error, so we can grow in the new life. Scripture is understood, then, to support and encourage movement and positive change: nourishment for growth (and growth is change), movement from sickness to health, while also providing safety and protection for both growth and good health.

These images also strongly imply that part of what it means to say we live in a fallen world is that people are in a weakened state, in poor spiritual health, likely to stray from the good path, likely to be tempted to leave the path that leads to fullness of health; and that therefore we all need the healing, nourishing, guiding, and protecting which the Scriptures are intended to provide as one important part of a whole treasury of healing in the Church. These various images also imply that entering into the new life in Christ isn't just a matter of mentally accepting some ideas as being true. If we need protection, then it isn't an easy process; it involves struggle, deep change, a cross.

II. Of course, if we are weak and sick with sin, we need healing and help-we need corrective lenses, a light to illumine the darkness we find ourselves in. And if we need to be changed, or transformed or purified, that also means that fallen humanity unaided and untransformed cannot properly see or perceive, hear or understand, true reality (see Mark 4:12)—especially spiritual realities, as one can notice many times in the gospel accounts.

The gospel accounts-and the New Testament as a whole-are full of exhortations about the need for positive change, the need to "bear fruit," to keep Jesus' words/commands-to "do the truth" (John 3:21), to live the gospel life. And we are called to do this, not because these are arbitrary rules like the speed limit, but because this is the only way to achieve the most profound personal 
transformation-a transformation which will be life-giving for ourselves and others, leading to true health, to "life in abundance," to eternal life in Christ. That's why this level of interpretation has been called "transformative (Fr. Theodore Stylianopoulos 1997). And because this personal transformation is understood to be the primary purpose of interpreting Scripture (and of life as a whole), it is the primary focus of the exegesis of those following the Orthodox Tradition-which is continuous with that of the early Church Fathers and the Apostles before them. This transformation always begins with a specific kind of change, often misunderstood today, called repentance.

Jesus often called for repentance. His first word in Matthew's gospel account is "Repent," and His first words in Mark's account concern the same theme (Matt. 4:17; Mark 1:15). In the Greek of the Fathers, repentance (metanoia) "signifies primarily a 'change of mind' or a 'change of the intellect' (nous): not only sorrow, contrition or regret, but more positively and fundamentally the conversion or turning of our whole life towards God (Palmer 1979, vol. 1, pp. 363-64)." According to St. John of Damascus, "Repentance is the returning from the unnatural into the natural state, from the devil to God, through discipline and effort." (St. John of Damascus 1979, vol. IX, p. 43)

So, secondly, all this means that there is real knowledge which is, as St. Paul says, "spiritually discerned"; and therefore, the "natural man," the unrepentant, uninspired, worldly person cannot perceive or have access to this knowledge as long as he or she is in that state (see I Cor. 2:14; see also Matt. 12:33-35). In other words, one's spiritual state determines whether one can perceive/know the most fundamental truths of Scripture, such as who Jesus Christ is and why this matters.

There is no sense here, or elsewhere in the gospel accounts, that one can acquire the kind of knowledge which Scripture is most concerned to impart by merely finding information about certain topics, or trying to be an "objective" observer, trying to interpret Jesus' actions and words accurately from a detached position. Again, how one interprets, one's very ability to interpret, or "see," depends directly upon one's spiritual state.

That's why St. Athanasius says, in concluding his classic work On the Incarnation ${ }^{1}$,

For the searching of the Scriptures and true knowledge of them, an honorable life is needed, and a pure soul, and that virtue which is according to Christ. So that the intellect, guiding its path by it, may be able to attain what it desires, and to comprehend it, in so far as it is accessible to human nature to learn concerning the Word of God. For without a pure mind and a modeling of one's life after the saints, a man could not possibly comprehend the words of the saints. For just as, if a man wished to see the light of the sun, he would wipe and brighten his eyes, purifying himself in some way like what he desires, and then he may see the light of the sun...thus he who would comprehend the mind of those who speak of God must begin by washing and cleansing his soul, by his manner of living, and approach the saints themselves by imitating their works. So that, associated with them in the conduct of a similar way of life, he may understand also what has been revealed to them by God. (St. Athanasius the Great 1979, vol. IV, p. 67)

III. So what does Scripture, and the Orthodox Church's Tradition as a whole, tell us about acquiring this kind of knowledge? What kind of training do we need to live an "honorable life" like the Saints? In a nutshell, we need to "put on Christ," to acquire the virtues, and free ourselves from the control of the negative passions (like anger towards others), and demonic deception, so that these passions like anger are only used as intended-as weapons against sin, especially our own sin, in order to build up the Body of Christ, and not to hurt others.

There is unanimity in the Tradition that the best way to acquire the Holy Spirit, the virtues, the good spiritual state necessary for fully understanding Scripture, is to live the gospel, which includes keeping ascetic

1 See also, e.g., (St. Ignatius Brianchaninov 1983), the chapter on carnal zeal; and St. Symeon the New Theologian, The Discourses, Chapter XXIV. 
practices, especially prayer, fasting, almsgiving. These disciplines help us overcome the negative passions, the lusts of the flesh that enslave us, our egotism, self-centeredness-the things that make it hard for us to be truly loving and for our hearts to be open to receive the Holy Spirit, to be illumined by Christ with "divine knowledge." We have to live the gospel in order to properly understand it.

And again, the fact that we need such illumination for a proper understanding of Scripture is also clear from the gospel accounts. Perhaps the most famous example is Christ walking with Luke and Cleopas on the road to Emmaus; but also in Luke 24:45, when the risen Jesus opened the eyes of all the apostles so that they could understand the Scriptures-especially, of course, those pertaining to Him. One could also include St. Paul's Damascus Road experience. This opening of their eyes involves much more than simple information about correct interpretations. "Did not our hearts burn within us...while he opened to us the scriptures?" the disciples say.

We can see this also, for example, in the prayer before the gospel in the Orthodox Liturgy of St. John Chrysostom, which begins,

Illumine our hearts, O Master, Who loves mankind, with the pure light of Thy divine knowledge, and open the eyes of our mind to the understanding of Thy gospel teachings; implant in us also the fear of Thy blessed commandments, that trampling down all lusts of the flesh, we may enter upon a spiritual way of life... (St. John Chrysostom)

There is a great emphasis on knowing and obeying the gospel commandments in virtually all writings of spiritual direction in our Tradition: that only if we obey the commandments, living the gospel way of life, can Scripture be life-giving to us. Christ Himself says in John 14:15, "If you love Me, you will keep My commandments. And I will pray the Father, and He will give you another counselor, to be with you for ever, even the Spirit of truth..." Living the gospel leads to communion with God, which means communion with the Spirit of truth, and such communion is necessary for properly understanding that truth.

St. Silouan of Mt. Athos, from the 20th century, repeats from his own experience the Church's same understanding from a different angle: "We may study as much as we will, but we shall still not come to know the Lord unless we live according to His commandments; for the Lord is not made known through learning, but by the Holy Spirit...To believe in God is one thing, to know God is another. Both in heaven and on earth the Lord is made known only by the Holy Spirit, and not through ordinary learning." (quoted by (Fr. Theodore Stylianopoulos 1980))

This also means, as indicated above, that many of the key aspects which Scripture is primarily concerned with (including, as in Matthew 12, who Jesus truly is) can only be fully, properly understood by being in a good spiritual state-by having a pure heart, or at least being repentant and striving for a pure heart, striving to live the gospel, and thus having one's heart illumined by the light of Christ. This reality-that one must live the gospel to fully/properly understand it, that one must be like the Saints in order to fully understand their words-has even been called by others "the fundamental rule" of traditional patristic exegesis ${ }^{2}$. This principle has also been called "the desert hermeneutic (Burton-Christie 1988; quoted by Paul Blowers (Blowers 1991))," though actually it is emphasized in all times and places by those following the apostolic and patristic Tradition.

Since this key principle has been entirely overlooked, or considered to be irrelevant, for several centuries in most non-Orthodox biblical studies, it is worth repeating: how you live your life is inseparable from being able to receive the illumination necessary to properly understand Scripture in its most important dimensions.

2 St. Justin Popovich, a contemporary Serbian Orthodox saint and scholar, says "the fundamental rule of Orthodox exegesis" is that you have to live the gospel in order to fully, properly understand it (see, e.g., (Popovich n.d.)). And that is why, for those in the patristic Tradition, and for those who follow them, Jesus Christ is the only true 'exegete of God.' Because He is God, He alone fully lives that reality (see John 1:18). 
IV. The fact that this spiritual knowledge is real and essential, and that you have to live the gospel to acquire this kind of knowledge that comes along with acquiring God's grace, is also why we in the Orthodox Church depend upon the Church Fathers and Saints for discerning the fundamentals of the Faith, and for providing the best interpretive context for our exegesis-why we base our interpretations of Scripture on their works, which are such a crucial part of our entire written Church Tradition. These are all people who are knowledgeable about God and the things of God from their own experience, whose interpretations/teachings as a whole have been confirmed by the Church as a whole, especially in the Ecumenical Councils (which in our Church have to be accepted by the people as a whole). That is why the Fathers are trustworthy guides for our reading of Holy Scripture, though we do not consider that anyone, other than Jesus Christ Himself, is somehow "infallible." The whole must be considered-or as St. Photius the Great (9th century) said, "The safe criterion of Orthodoxy is the majority [of Church Fathers]." ${ }^{3}$

St. John Chrysostom (4th century) explains this further with a helpful analogy:

It behooves us therefore to explore everything carefully. For the words of the Scripture are our spiritual weapons; but if we do not know how to fit those weapons and to arm our scholars rightly, they keep indeed their proper power, but they cannot help those who receive them. For let us suppose there to be a strong corselet [a piece of armor that covers the trunk of the body], and helm(et), and shield, and spear; and let one take this armor and put the corselet upon his feet, the helmet over his eyes instead of on his head, and let him not put the shield before him..., but perversely tie it to his legs: will he be able to gain any advantage from the armor? Will he not rather be harmed? It is plain to anyone that he will. Yet this is not on account of the weakness of the weapons, but on account of the unskillfulness of the man who knows not how to use them well. So with the Scriptures-if we confound their order, they will even so retain their proper force, yet will do us no good. (St. John Chrysostom 1979, vol. XIV, p. 105)

We depend on the Fathers and the interpretive context of Tradition in order to best learn how to use the "spiritual weapons" which Scripture provides us with, so that we too can have spiritual victory in our lives. At this point in time, we have many hundreds of years and many thousands of people (including living saints) to verify the effectiveness of the Fathers' and Saints' understanding in helping us to become holy, so we very reasonably accept it to be true. Additionally, in the Orthodox Church, although the early Fathers have a special pre-eminence for a variety of reasons, the period of the Fathers never ends; there are a number of holy, learned theologians even in our own time who are widely recognized in the Church as ranking among the Fathers of the Church-though more time must pass before we see how influential their writings and lives have been and how lasting their influence will be.

V. The idea of depending on the Fathers for our basic interpretive context for Scripture, and even for their wisdom about specific passages, never has meant that people were not encouraged to read Scripture themselves. From the beginning of Church history, except when in a situation of oppression and general lack of education (or habits derived from those times!), those in the mainstream Tradition have emphasized the importance of reading and studying Scripture for all who are able to.

To give a quick cross-section through time-in the 4th century, St. John Chrysostom, who urged all his parishioners to read Scripture at home and discuss the sermon as a family, says, "for this is the cause of all evils—not knowing the Scriptures."4 St. John of Damascus in the 8th century wrote:

(Ford 2015, p. 315). Some of the material in this paper appears in this book.

4 (St. John Chrysostom 1979, vol. XIII, p. 301). By Chrysostom's time, he can assume that in large cities almost every parishioner will have at least a copy of the four gospels that they can read at home. There were scriptoria where up to 100 scribes would make copies of Scripture as it was being dictated_producing up to 1000 copies a month. 
To search the Scriptures is a work most fair and most profitable for souls. For just as the tree planted by the channels of waters, so also the soul watered by the divine Scripture is enriched and gives fruit in its season... Wherefore let us knock at that very fair garden of the Scriptures.... let us not knock carelessly but rather zealously and constantly. For thus it will be opened to us. If we read once or twice and do not understand what we read, let us not grow weary, but let us persist, let us talk much, let us inquire... let us luxuriate, let us revel insatiate." (St. John of Damascus 1979, vol. IX, p. 89)

And from the 19th century, St. Ignatius Branchianinov says (of a monk, but, as Metr. Kallistos [21st century] has explained, it applies to lay people as well): he/she "should devote all possible care and attention to the reading of the Holy Gospel. He should study the Gospel so closely that it is always present in his memory...Keep on studying the gospel until the end of your life. Never stop. Do not think that you know it enough, even if you know it all by heart." (Ware 1987, p.147)

VI. A sixth fundamental is that because God is the good God Who loves mankind, He has arranged for the fallen world a salvation economy (the Incarnation, etc.) that includes an ascetic economy, to help us in our healing, our transformation, our repentance. This means in part that difficulties and trials are a crucial aspect of the "spiritual pedagogy" that the Lord has arranged in this world ultimately for the salvation of humankind. You have to properly enter into that asceticism, you have to use the tools reality gives you, so to speak, in order to make spiritual progress and to properly understand both Scripture and life. You have to undergo ascetic efforts in the proper spirit to purify your heart in order to become holy, to acquire the Holy Spirit-or however you may wish to talk about this spiritual reality.

In other words, the spiritual struggle, or any difficulties in life, are not punishments, or "imperfections" that should not be there-something that is wrong. Rather, they are an important and valuable aspect of reality that we should not only expect to be there, but if approached in the proper way, we should expect them to benefit us, and thus we can actually also be grateful for them. As St. Gregory the Theologian (4th century) says even about the expulsion of Adam and Eve from Paradise, and everything that came with their Fall, "the penalty becomes an act of compassion. ${ }^{\text {" And }}$ as St. John Chrysostom says of death, the greatest "difficulty" in the fallen world, "even though death entered as a result of sin, nevertheless such is the superiority of God, His lovingkindness, and the excess of His care that He employs even this to the advantage of our race." (St. John Chrysostom 1999, vol. 2, p. 37, on Psalm 111)

Indeed, Archimandrite Vasileios can even say,

In the end, the faithful will thank God only for great sufferings, for complete "perplexities." In other words, everything will be swept away by the fire of praise. And the cooling flame of unbearable fire will leap up from the painful occurrences, the temptations and the thorns that we did not wish to undergo, considering them to be obstacles, a curse making our lives miserable. For we had not realized that for the man who is placed rightly... obstacles blocking the road are nothing other than steps which take him upwards and opportunities to give praise. For it is the Lord who is at work in everything (Vasileios 1984).

This understanding is simply the direct continuation of what is very evident in many places in the New Testament. For example, St. James says, "Consider it pure joy, my brethren, whenever you face trials of many kinds, because you know that the testing of your faith develops perseverance" (James 1:2-3; my emphasis). And as Christ Himself says in St. John's gospel, "In the world you have tribulation; but be of good cheer, I have overcome the world" (John 16:33).

5 Quoting from St. Gregory the Theologian's Oration 45, on Easter, part 8, excerpt given in Panayiotis Nellas (Nellas 1987), Deification in Christ: The Nature of the Human Person. 
VII. Another fundamental presupposition to be discussed here is related to that just above. Reality is set up with many analogous aspects; in this case, difficulties in everyday life are analogous to difficulties in interpreting Scripture, and thus should be approached in the same spirit. More will be said about this shortly.

VIII. The last foundational principle is that a critical part of the interpretive context for Orthodox Christians is the liturgical use of Scripture. In a real way, this is first-it's the context in which Scripture was primarily intended to be encountered. Every service in our Church is filled with references to Scripture, quotations from Scripture, as well as the reading of entire passages. During the services of the Church, the faithful are "bathed" in Scripture, its phrases and images, and reflections on it.

A very clear example of how important and valuable this is can be seen in the services celebrating the Transfiguration of Our Lord on August 5th and 6th. In these services, in the context of many beautiful hymns explaining the proper understanding of this event described in the gospel accounts, one finds not only the gospel accounts of Matthew and Luke read, but also 2 Peter 1:10-19, where Peter speaks of the Apostles being "eyewitnesses of His majesty." During Vespers, several key Old Testament theophanies are read which illuminate how this event should be understood: Exodus 24:12-18-the children of Israel seeing the glory of the Lord on Mt. Sinai; Exodus 33:11-23 and 34:4-6, 8-Moses seeing the "back parts" of God; and 1 Kings 19:3-9, 11-13, 15-16- the theophany in the still small voice given to Elijah.

Below are a few of the hymns from the Vespers service, in which we notice how key foundational principles of the interpretive context mentioned above are reinforced in a way very characteristic of Orthodox services:

Before Thy Crucifixion, O Lord, taking the disciples up into a high mountain, Thou wast transfigured before them, shining upon them with the bright beams of Thy power. From the love of mankind and in Thy sovereign might, Thy desire it was to show them the splendour of the Resurrection. Grant that we too in peace may be counted worthy of this splendour, O God, for Thou are merciful and lovest mankind (Mother 1969, p. 470).

When Thou wast transfigured, O Saviour, upon a high mountain, having with Thee the chief disciples, Thou wast shone forth in glorious majesty, proving thereby that those who surpass in the height of their virtues shall be counted worthy of the divine glory. Talking with Christ, Moses, and Elijah showed that He is Lord of both the living and the dead [Romans 14:9], the God Who spoke of old through the Law and the Prophets. And the voice of the Father testified to Him from the cloud of light, saying, "Hear ye Him, Who through His cross harrows hell and gives the dead eternal life (Mother 1969).

O Christ our God, Who wast transfigured in glory on Mount Tabor, showing to Thy disciples the splendour of Thy Godhead, do Thou enlighten us also with the light of Thy knowledge, and guide us in the path of Thy commandments, for Thou alone are good and lovest man (Mother 1969, p. 474).

He Who once spoke through symbols to Moses on Mount Sinai, saying, "I am He Who is" [Ex. 3:14], was transfigured today upon Mount Tabor before the disciples; and in His own person He showed them the nature of man, arrayed in the original beauty of the Image. Calling Moses and Elijah to be witnesses of this exceeding grace, He made them sharers in His joy, foretelling His decease through the Cross and His saving Resurrection (Mother 1969, p. 476).

Another important element of the patristic analogies for Scripture which many emphasize is the enjoyment of beauty in reading/hearing Scripture. Scripture is compared to a fragrant garden; a garden with many beautiful flowers; a beauty of treasures leading to delight, wonder, and praise. Orthodox liturgical services, in which hymns such as those above are sung, very much emphasize this 
"atmosphere" of beauty as well. All the senses are involved through the sung services, the beautiful icons, the fragrant incense, various movements-indeed, the whole body is being "soaked" in beauty as an essential part of worship wherever possible. This is a way to physically experience that the God we worship is the good God Who loves us, Who does everything for our benefit, Who is worthy of our worship.

The beautiful services intend in part to inspire "good eros"- the desire for union with this good God in Christ through the Holy Spirit. St. Basil the Great said after his dramatic experience of God's uncreated light (or glory), "What is more marvelous, more worthy of love, than the beauty of God." Our services intend to evoke a similar feeling and awareness in worshipers, giving a foretaste of the paradise that is the heavenly kingdom, and increasing our desire for that inexpressibly beautiful life in union with the One most worthy of love.

Even from these brief examples and description, hopefully the non-Orthodox reader can get a glimpse of what Archimandrite Vasileios describes when he says, "The Church does not give us Holy Scripture as a book to study and interpret on our own. Rather, it opens to us the door of that beauty to which we are called by the Bridegroom Himself." This beauty is meant to inspire us to undertake with love and joy the ascetic labors necessary for real spiritual transformation.

St. Macarios the Great (4th century) gives a helpful analogy when he says that a Christian

should every day have the hope and the joy and the expectation of the coming kingdom and deliverance, and to say, "If today I have not been delivered, I shall tomorrow." As the man who plants a vine has the joy and the hope in himself, before he ever embarks upon the toil, and sketches out vineyards in his mind, and reckons up the income, when there has been no wine yet, and so enters upon the toil-for the hope and expectation make him labour cheerfully...and in like manner the man who builds a house and the man who tills a field, are at much expense to themselves first, in hope of the advantage to come; so it is here. If a man does not keep before his eyes the joy and the hope, "I shall find deliverance and life," he cannot endure the afflictions, or the burden, and adopt the narrow way. It is the presence of hope and joy that make him labour and endure afflictions (St. Macarius the Great 1974, p. 190).

It is also the ascetic dimension that helps prevent all the beauty from being merely aesthetic, superficial appreciation or pleasure.

These fundamentals of Orthodox theology and life- the truth of which has been experienced by myriads of Christians through the centuries, and have been confirmed by the Church as a whole-provide a radically different interpretive context for the use of any methods or tools of interpretation from the essentially agnostic approach promoted by Spinoza and those who have followed in his footsteps who have exclusively used the historical critical method, whose foundation was to "interpret as if there is no God." Indeed, the whole "Enlightenment" project, which began to dominate biblical studies after the intense and sometimes violent conflicts following the Reformation, with its impossible attempt to have "Scripture alone," rejects all of the Orthodox fundamentals mentioned above.

The "Enlightenment" world-view does not believe in a "good God Who loves mankind, Who does everything for our benefit"; so it cannot understand the ascetic dimension of reality in a positive way, but regards difficulties in biblical interpretation (as in life) as imperfections, things that shouldn't be there (especially if God were good, or if this were a divinely inspired text). Difficulties are then usually regarded as indications that the biblical author/redactor failed in some way (clumsy editing, etc.). The assumption often seems to be that such difficulties surely would not be there if the biblical authors were as intelligent and well-informed as their later interpreters! Of course, this secular view does not see the world as a revelation of God, or His careful organizing of reality for our salvation. Rather, things are as they are, it is claimed, as a result of impersonal, purposeless natural forces with no meaning beyond their own existence. 
This seems to me to be the heart of the difference between a truly Orthodox understanding and use of Scripture and what has prevailed in most non-Orthodox scholarly circles. ${ }^{6}$ This means that the differences are not primarily anything to do with methodologies, or techniques as such-though these do differ in various ways-but fundamentally they are about theology.

From an Orthodox perspective, all the basic technical aspects of historical criticism-linguistic studies, looking at the historical context, etc.- -when removed from the agnostic interpretive context of historical criticism can be valuable tools leading to a deeper understanding. That is why I believe it is helpful to distinguish these techniques used apart from that Spinozan interpretive context by calling them "the techniques of biblical criticism" as distinct from "historical criticism." Nevertheless, regardless of how helpful these techniques may be in understanding certain passages, they cannot be considered essential for the primary purpose of Scripture to be fulfilled: for people to become holy, to know God through their purified hearts-to be in loving communion with Him and one another. For that goal/telos, living the gospel is the essential "method."

Of course, the need to find a way to determine authoritative interpretations of Scripture in the aftermath of the Reformation and the so-called "Wars of Religion" led many to look for a "scientific" approach that all reasonable people would have to accept—an approach which could safely ignore or bypass not just the Church and her Tradition, but also any sense of the need for purifying the heart, of a gospel way of life necessary before proper interpretation could take place.

Gradually in many circles, the focus shifted from things which cannot be determined by any scientific method, which are not even appropriate subjects for scientific study alone-such as what is true? what leads to holiness, communion with God, fulness of life, salvation?-to aspects that could be studied by the new scientific methods, such as attempts to determine the "original" text, historical circumstances, etc. Certainly, technical information has been valued by the highly educated Church Fathers and used when available; but because it was not germane to the primary purpose of Scripture, these aspects were never primary, and certainly could not properly be the exclusive focus.

Hence, while taking advantage of any information or insights gained through biblical critical techniques, archaeology, etc., the Orthodox exegete today who wishes to follow our Tradition will always start with the principles given above, along with the entire interpretive context provided by the Tradition; and they will consult the patristic witness where possible on specific passages.

The following analogy of Macarios the Great about spiritual life is equally true for the work of interpreting Scripture. As he says,

In the outer world, the husbandman tills the ground; but in spite of his tilling, he needs rain and showers from above. If no moisture comes from above, the husbandman has no profit from his tilling of the ground. So it is with the spiritual world... The man must cultivate with a will the ground of his heart, and labour upon it.... But unless clouds of heaven make their appearance from above, and showers of grace, the husbandman does not profit by his toil (St. Macarius the Great 1974).

Partly because this is the case, it does not follow that exegetes who follow the Orthodox tradition believe the Fathers have exhaustively interpreted Scripture, and all that's left to do is to restate what they've said. The Holy Spirit can inspire exegetes in all eras. This is clear from the analogies for Scripture of the early Fathers themselves stressing its endless depths and riches-that there is no end to what one can see and learn. There is no trace of the idea that exegetes must find the one original historical meaning in order to really understand Scripture. Rather, it is compared to a vine with endless fruit; endless wealth, a never-failing spring; a meadow with diverse flowers, copious fruit,

6 Protestant Fundamentalists also share the attitude that difficulties in the interpretation of Scripture are imperfections which shouldn't be there, since every verse must have a clear interpretation. And there can be no small, incidental factual errors of any kind, even if they were believed by everyone at the time the passage was written. Of course, this is all also a legacy of the untenable "Scripture alone" approach. 
and abundant fragrance - a paradise of flowers and fruit; a fair garden with varied sounds; a treasure chest with inestimable riches and precious stones; and the rock which Moses struck with oceans of water springing from it. It is said to possess inexhaustible grace.

So, while basing our interpretations on those of the exegetes who have gone before us whose wisdom is confirmed by the Church, and its "rule of Faith" - those truths of the Faith which will never change-we realize that there is always more to say. And we can pray for wisdom and guidance to say what those who are hearing or reading what we say need to hear for their spiritual benefit.

Finally, in evaluating certain exegetes and the worth of their exegesis, it is not enough only to discern if they have given readers correct information. I would suggest that readers would do well to ask about some things that are just as important: are these exegetes being "nourished and renewed by their own theology"? Are they "a support and joy for the Church" (Ford 2015, p. 282)? Are they "passing on the joy" of life in Christ in a life-giving way as the Fathers always have (Vasileios 1984, p. 35)? This is certainly a vital part of what traditional Orthodox Christian exegetes of all times and places hope to do!

Conflicts of Interest: The author declares no conflict of interest.

\section{References}

Blowers, Paul. 1991. Exegesis and Spiritual Pedagogy in Maximus the Confessor: An Investigation of the Quaestiones ad Thalassium. South Bend: University of Notre Dame Press, p. 38.

Burton-Christie, Douglas. 1988. Scripture and the Quest for Holiness in the Apophthegmata Patrum. Ph.D. Dissertation, Theological Union, New York, NY, USA.

Ford, Mary. 2015. The Soul's Longing: An Orthodox Perspective on Biblical Interpretation. South Canaan: St. Tikhon's Monastery Press.

Fr. Theodore Stylianopoulos. 1980. Bread for Life: Reading the Bible. Brookline: Dept. of Religious Education, Greek Orthodox Archdiocese of North and South America, p. 37.

Fr. Theodore Stylianopoulos. 1997. The New Testament: An Orthodox Perspective. Brookline: Holy Cross Orthodox Press, chp. 3.

Mother, Mary. 1969. The Festal Menaion. London: Faber and Faber.

Nellas, Panayiotis. 1987. Deification in Christ: The Nature of the Human Person. Crestwood: St. Vladimir's Seminary Press, p. 204.

Palmer, G.E.H. 1979. The Philokalia. London: Faber and Faber, vol. 1, pp. 363-64.

Popovich, Justin. n.d. How to Read the Bible and Why. Available online: http://www.sv-luka.org/library/ howtoread_jp.htm (accessed on 16 March 2017).

St. Athanasius the Great. 1979. On the Incarnation. In Nicene and Post-Nicene Fathers. Second Series. Grand Rapids: Eerdmans, vol. IV, p. 67.

St. Ignatius Brianchaninov. 1983. The Arena. Jordanville: Holy Trinity Monastery, pp. 140-44.

St. John Chrysostom. 1979. Homily IX on Colossians. In Nicene and Post-Nicene Fathers. First Series. Grand Rapids: Eerdmans.

St. John Chrysostom. Divine Liturgy of St. John Chrysostom. In Service Books of the Orthodox Church. South Canaan: St. Tikhon's Seminary Press, vol. 1.

St. John Chrysostom. 1999. Commentary on the Psalms. Translated by Hill Robert Charles. Brookline: Holy Cross Orthodox Press, vol. 2, p. 37.

St. John of Damascus. 1979. Exact Exposition of the Orthodox Faith. In Nicene and Post-Nicene Fathers. Second Series. Grand Rapids: Eerdmans.

St. Macarius the Great. 1974. Fifty Spiritual Homilies. Willits: Eastern Orthodox Books.

St. Symeon the New Theologian. 1980. The Discourses. New York: Paulist Press.

Vasileios, Archimandrite. 1984. Hymn of Entry. Crestwood: St. Vladimir's Seminary Press. 
Vasileios, Archimandrite. 1997. The Christian in a Changing World. Montreal: Alexander Press. Vasileios, Archimandrite. 2012. Hymn of Dismissal. Crestwood: St. Vladimir's Seminary Press. Ware, Bishop Kallistos. 1987. The Orthodox Way. Crestwood: St. Vladimir's Seminary Press.

(C) 2017 by the author. Licensee MDPI, Basel, Switzerland. This article is an open access article distributed under the terms and conditions of the Creative Commons Attribution (CC BY) license (http://creativecommons.org/licenses/by/4.0/). 